\title{
Bone Marrow, Humerus
}

National Cancer Institute

\section{Source}

National Cancer Institute. Bone Marrow, Humerus. NCI Thesaurus. Code C77687.

Bone marrow in the humerus bone. 